\title{
Building Disaster Resilient Local Economy: The Case of the Philippines
}

\author{
Marjorie Don Resuello \\ Graduate School of International Development, Nagoya University, Japan
}

Received: Sept. 28, 2020 Accepted: Nov. 11, 2020 Online published: Nov. 25, 2020

doi:10.5296/jpag.v10i4.17752ＵRL: https://doi.org/10.5296/jpag.v10i4.17752

\begin{abstract}
The study explored the key trends and various issues surrounding disaster risk reduction and management (DRRM) in the Philippines by analyzing the interrelationship of disaster risk, revenue generation capacity, and DRRM capacity of local governments in the Philippines. The study analyzed the economic implications of disasters to the local economy and analyzed how revenue generation capacity of local governments contributes to realizing disaster-resilient local economy. The study found out that while the law encourages local governments to invest on DRRM, the current system, however, puts local governments with lower income at a disadvantage as they have lower revenues and thus, less resources to utilize for DRRM. The varying income among local governments create disparity not just in local growth but also in performing their DRRM devolved functions. Therefore, the revenue generation capacity of local governments is crucial to strengthen DRRM at the local level. The study suggests that addressing disparity in income and the complexities in sourcing the local revenue as well as having entrepreneurial and transformational local chief executives are crucial factors to realize disaster-resilient local economy in the Philippines.
\end{abstract}

Keywords: disaster, disaster risk reduction and management, revenue generation, local governments, Philippines

\section{Introduction}

The Asia-Pacific Region has been known as the most disaster-prone region in the world. It has faced growing frequency and severity of natural disasters as triggered by the climate change. In 2018, the region was devastated by eight out of ten deadliest disasters in the world and was hit by almost half of the 281 natural disasters worldwide (UNESCAP, 2019). Over the past two decades (1996-2015), six out of ten countries which were most affected by weather-related disasters were developing countries from the Asia Pacific Region based on the Global Climate Risk Index Report 2017. This shows the vulnerability of poor countries and how they are hit much harder as attributed to low adaptive capacity due to high exposure 
to disasters at the same time low stage of economic development (Kreft, Eckstein, \& Melchior, 2016).

The archipelagic country of the Philippines has been ranked as the third most disaster-risk country in the world among over 170 countries from 2011 to 2019 based on the Global Climate Risk Index Report (Kreft, Eckstein, \& Melchior, 2016). This is due to the country's high susceptibility from natural disasters which includes hydrological, meteorological, and geophysical types of disaster. This consistent high ranking of the Philippines serves as a warning sign of being a highly disaster-risk country and reflects its minimal improvement over the past decade to mitigate the impacts of disasters.

National efforts have been made such as the enactment of the Philippine Disaster Risk Reduction and Management Act of 2010 (hereafter referred to as Philippine DRRM Act) and the Climate Change Act of 2009 alongside the development of DRRM-CCA salient and integrated plans/frameworks in order to build resilience to natural disasters and climate change. In the context of Philippine decentralization, local governments are seen as frontlines to respond to natural disasters in their jurisdiction and the prime movers to generate local sources to perform their devolved functions in which among them is DRRM. That is, local governments are responsible to generate resources to implement DRRM interventions at the local level.

As acclaimed by a senior official, with increased magnitude and frequency of disasters affecting economic development, the burden is overwhelming with disaster after disaster has struck the Philippines and rehabilitation in one area was hardly past the first stage yet another disaster strikes again (Bankoff, 2003). The impacts of disasters are localized (Benson, 1997). The likelihood of occurrence of disasters was identified as a factor that strain financial capacity of local governments (National Association of Development Organizations \& Rural Policy Research Institute, 2013).

Understanding of disaster and climate change impacts and investing on DRRM are paramount to further safeguard the society from future impacts of adverse events (Christoplos, 2015). In addition, understanding risk is at the heart of building resilience to disasters. Disasters can have a considerable financial impact on local governments, but this impact has not been systematically analyzed (Chen, 2019). As far as the author is aware, there is no study conducted yet that provides understanding on the local impacts of disaster to local governments in the Philippines, particularly on its revenue generation and thereby DRRM capacity. Further, it speculated that the impact of disasters tended to vary depending on their revenue generation capacity, thereby affecting their DRRM capacity.

Ten years upon enactment of the Philippine DRRM Act, it is an opportune time to analyze the disaster risks the local governments have faced and their implication to revenue generation and DRRM. In this context, the study aimed to identify the interrelationship among disaster risk, revenue generation, and DRRM capacity. The findings of the study provided local governance perspective which can contribute to holistic approach in realizing disaster-resilient local economy. Studying the impacts of disaster on the local economy is worth focusing on, especially in the decentralized developing countries like the Philippines 


\section{Macrothink}

which is highly vulnerable to disaster risks.

\section{Method}

\subsection{Conceptual Framework}

The study analyzed the interrelationship of disaster risk, revenue generation capacity, and DRRM capacity of the local governments towards building disaster-resilient local economy in the Philippines as illustrated in Figure 1.

Disaster Risk. Disaster risk refers to the exposure to and impacts of natural disasters at the local level. In this study, it is measured by identifying the disaster incidents as well as the disaster impacts which refer to the number of affected populations, fatalities, and damage to properties.

Revenue Generation Capacity. Following the logic that poor are vulnerable to hazards, revenue generation capacity as a variable of the study reflects the vulnerability of local governments to natural disasters by considering their varying revenue generation capacity. This is aligned to the provision of the law that local governments are corporate entities with revenue generation powers and responsibilities to perform its various devolved responsibilities, with this study specifically focusing on DRRM. Hence, with specific focus is on revenue generation, the study identified the total revenue, sources of revenue, and self-sufficiency rate of the levels of local governments.

DRRM Capacity. In this study, this corresponds to the use of the generated total revenue to appropriate local DRRM funds which are used for DRRM interventions at the local level. It primarily considers the LDRRMF appropriation and the LDRRMF actual collections among local governments.

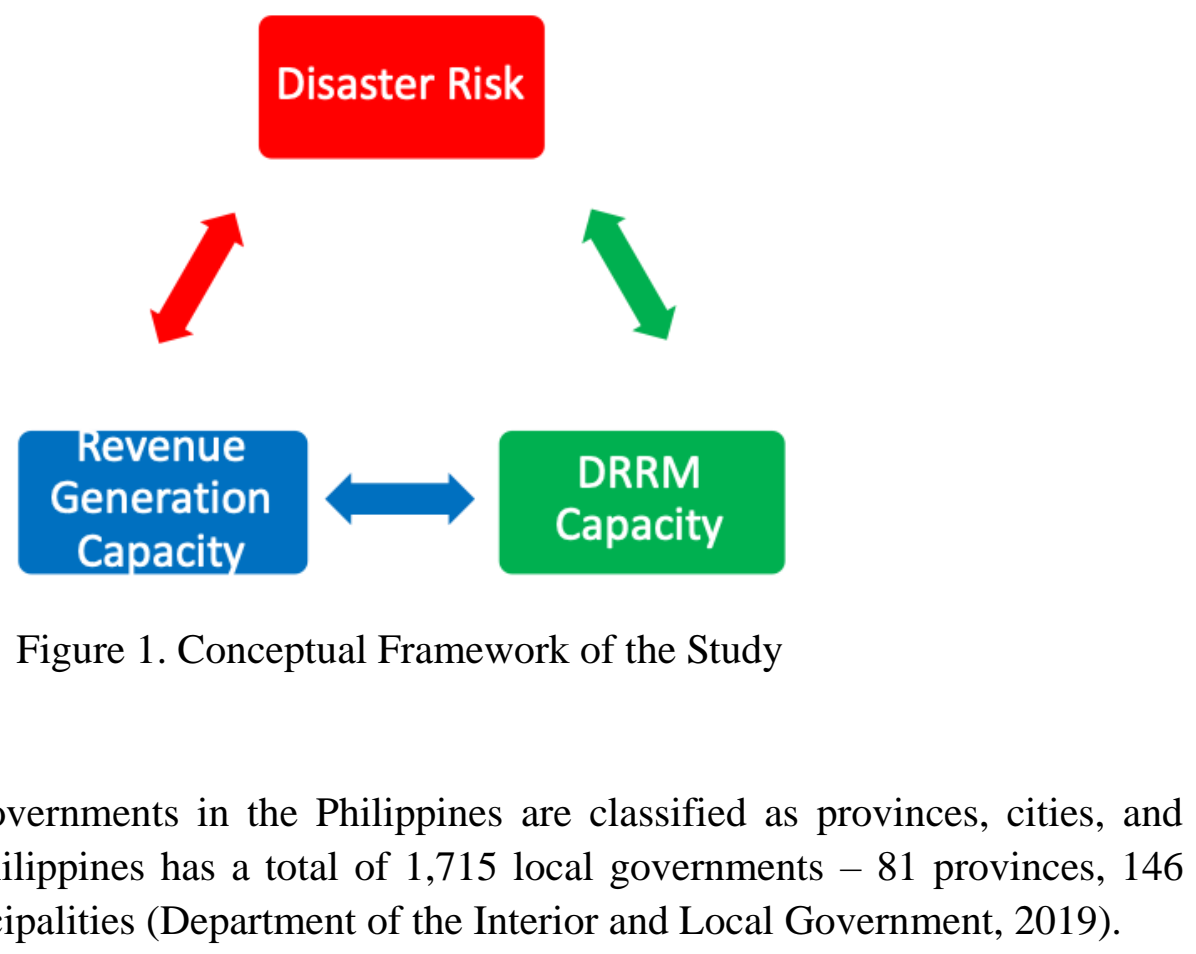

\subsection{Data Collection}

The levels of local governments in the Philippines are classified as provinces, cities, and municipalities. The Philippines has a total of 1,715 local governments - 81 provinces, 146 cities, and 1,488 municipalities (Department of the Interior and Local Government, 2019). 


\section{MlMacrothink}

Journal of Public Administration and Governance

ISSN 2161-7104

2020, Vol. 10, No. 4

The statistical data used in the study was retrieved from the national governments in the Philippines as well as international organizations. Among these are the Bureau of Local Government Finance, National Disaster Risk Reduction and Management Council, Department of the Interior and Local Government. The financial data of the local governments in the form of financial statements from 2010-2019 were obtained from the Bureau of Local Government Finance website. The data includes the annual income, revenue generated, and revenue sources. Moreover, the Local DRRM Fund appropriation and collection was directly requested from the Bureau of Local Government and Finance, in which 2018 data was the only one available. The disaster occurrences and damages in 2010-2019 were from the incidence reports from the Office of the Civil Defense, National Disaster Risk Reduction and Management Council.

\subsection{Data Analysis}

The study used the mixed methods research methodology, specifically case study approach in the Philippines. The data collected in this study were analyzed using descriptive statistics and inferential statistics. Time series analysis was employed in the study as a statistical technique to identify trends and patterns in disaster risks, revenue generation capacity, and DRRM capacity over the recent past decade (2010-2019) of the local governments. The year 2010 serve as the baseline of the research as it is the year when the Philippine DRRM Law was enacted as well as to analyze the harmonization of performance of DRRM mandates and corporate powers of the local governments after about three decades upon enactment of the Local Government Code of 1991.

In analyzing the revenue generation capacity of the Philippine local governments over the past decade (2010-2019), this study adapted the variables from the 10-point test of Financial Condition which was used to measure fiscal health of the government, particularly the revenue which are categorized as follows: local revenue, external revenue, and sources of revenue (Brown, 1993). Brown's computation was adapted to identify local revenue dependency and IRA dependency. The local revenue dependency is measured as total local revenue divided by total income, while the IRA dependency is calculated by dividing the IRA over total income. From this, the study employed descriptive-analytic analysis of the revenue generation capacity of the local governments based on their income growth, sources of income, and self-sufficiency rate.

Disaggregated data based on level of local governments (province, city, municipality) was analyzed and compared to each other to draw further analysis. The empirical and analytical foundations with reference to the ten-year period from concerned agencies as well as high-quality literature were used in the analysis of this chapter.

To examine the relationship among disaster risk, revenue generation capacity, and DRRM capacity, simple correlation analysis was employed in this study. The Pearson's correlation coefficient was used to interpret the findings, using the following guidelines in Table 1 . 
Table 1. Pearson's Correlation Coefficient

\begin{tabular}{|l|c|c|}
\hline \multirow{2}{*}{ Strength of Association } & \multicolumn{2}{|c|}{ Coefficient, $\mathbf{~}$} \\
\cline { 2 - 3 } & Positive & Negative \\
\hline No correlation & 0 & 0 \\
\hline Low & 0.1 to 0.29 & -0.1 to -.029 \\
\hline Moderate & 0.3 to 0.49 & -0.3 to -0.49 \\
\hline High & 0.5 to 0.99 & -0.5 to -0.99 \\
\hline Perfect & 1 & -1 \\
\hline
\end{tabular}

\section{Disaster Risk in the Philippines}

The Philippines is one of the top disaster-risk countries in the world due to its high exposure, high vulnerability, and lack of coping capacity to disasters based on Global Climate Risk Index by Germanwatch and UNU-EHS's INFORM risk index. The high disaster risk profile of the Philippines manifested with catastrophic disasters it experienced from 2010 to 2019 - a total of 1,442 recorded natural disasters (Figure 2) which caused damage to properties amounting to PhP405.54 billion (Figure 5), affecting 103 million people (Figure 3) and causing 11,558 casualties (Figure 4). Its inherent exposure to natural disasters is attributed to its geographical location being situated in the tectonically active Pacific Ring of Fire and typhoon belt in the Pacific, thereby making in highly exposed to earthquakes and tropical cyclones. Disasters have always been a perennial problem for the country, causing mass casualties and destruction of millions of properties.

The tropical cyclones, while lower in number of incidents compared to other disasters, were the most reoccuring and destructive disaster. A total of 162 tropical cyclones frequented the country in which 97 made landfall (Figure 2). That is an average of 18 tropical cyclones, in which 11 made landfall and caused consequent damages.

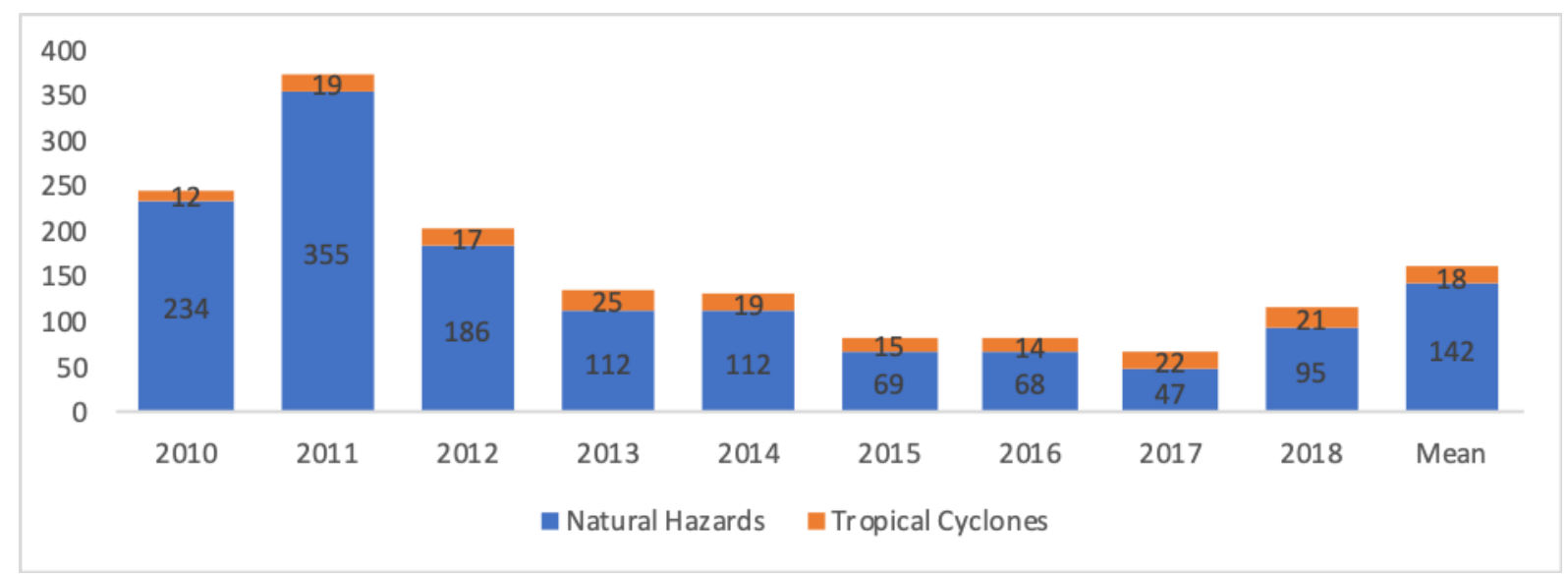

Figure 2. Number of Incidents of Natural Hazards and Tropical Cyclones in the Philippines (2010-2018). Source: NDRRMC, Incidents Reports, various years (2010-2018)

Overall, tropical cyclones caused an average of $74 \%$ of the total affected population (Figure 3 ), $89 \%$ of the casualties (Figure 4) and $89 \%$ of the total damages (Figure 5) in 2010-2019. Moreover, tropical cyclones create conditions for another types of disasters such as heavy 


\section{Macrothink}

Journal of Public Administration and Governance

ISSN 2161-7104

2020, Vol. 10, No. 4

rains, flooding, and strong winds which result in heavy casualties and damage. Some of the most devastating floods and landslides are triggered by these typhoons that happened also within this period.

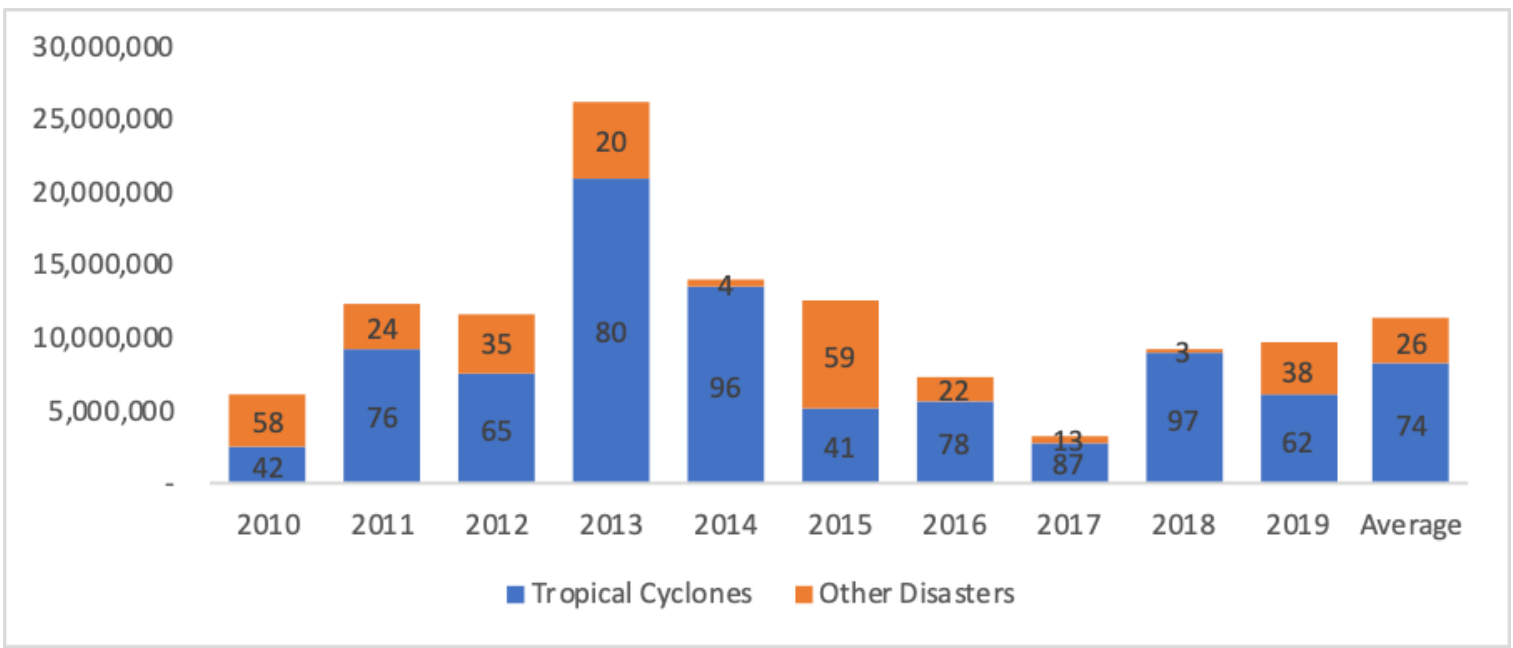

Figure 3. Number and Ratio (\%) of Affected Population by Tropical Cyclones and Other

Disasters (2010-2019). Source: NDRRMC, Incidents Reports, various years (2010-2019)

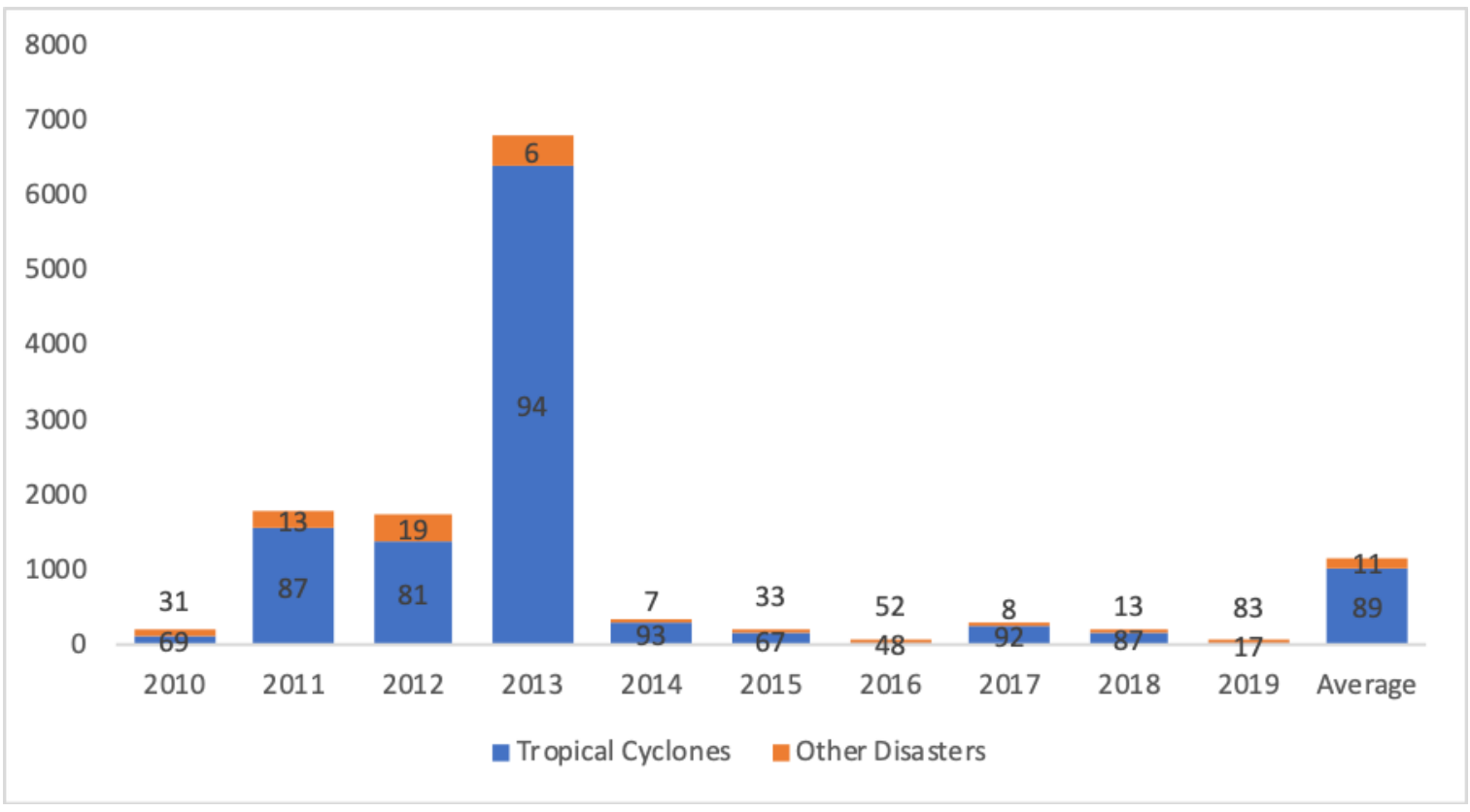

Figure 4. Number and Ratio (\%) of Casualties Caused by Tropical Cyclones and Other Disasters (2010-2019). Source: NDRRMC, Incidents Reports, various years (2010-2019) 


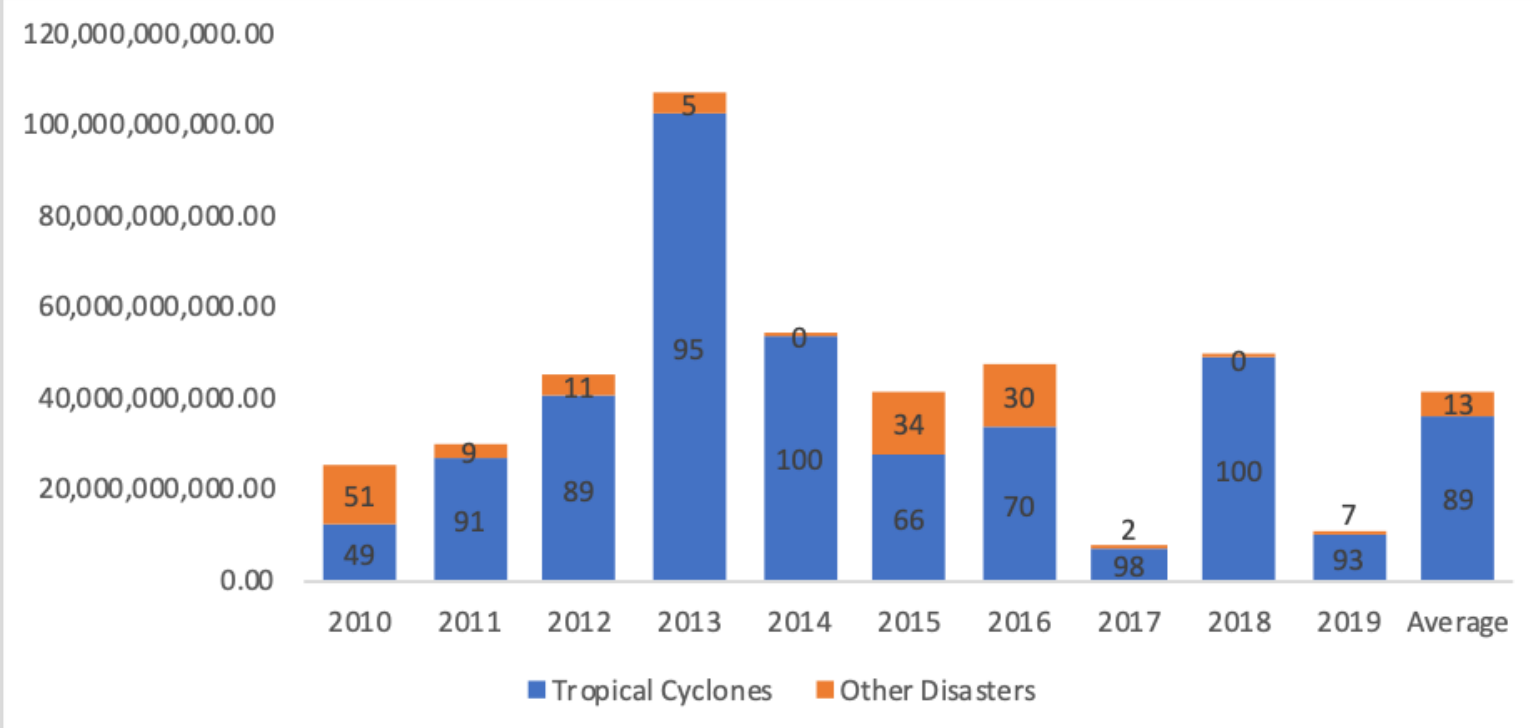

Figure 5. Amount and Ratio (\%) of Damages Caused by Tropical Cyclones and Other Disasters (2010-2019). Source: NDRRMC, Incidents Reports, various years (2010-2019)

The year 2013 was consistently with the highest number of affected people and casualties as well as amount of damages. This was caused predominantly by the onslaught of a single typhoon - the Typhoon Haiyan, which is locally known as Typhoon Yolanda. Typhoon Haiyan made landfall to the Philippines in 2013. The geographic area affected by Typhoon Haiyan was extensive. The typhoon devastated 44 provinces, 591 municipalities, and 57 cities in nine out of 17 regions (Cinco, et al., 2016).

Moreover, Typhoon Haiyan caused destruction in the lives of more than 3.4 million families or 16 million people which is equivalent to $61 \%$ of the total affected population in 2013 , which accounted $16 \%$ of the total affected population in 2010-2019. The year 2013 was also the year with the highest number of casualties attributed to Typhoon Haiyan with a total of 6,300 casualties, which is $55 \%$ of the country's total casualties in the nine-year period. Corollary to the highest number of affected population and casualties in 2013 due to Typhoon Yolanda, it caused the biggest damages amounting to PhP95.48 billion or $89 \%$ of the total damages in 2013. In the nine-year period, $24 \%$ of the total damages was caused by Typhoon Yolanda. The largest normalized economic loss is associated with the Typhoon Haiyan in 2013 (Cinco, et al., 2016). From these catastrophic damages and as acclaimed by the experts, Typhoon Haiyan was one of the strongest typhoons ever in the world which made landfall in the Philippines.

Moreover, in the year 2010 and 2015, the single occurrence of periodic El Nino Southern Oscillation have incurred high economic costs and resulted to massive population and extensive localities affected. Therefore, disaster risk in the Philippines shows that the country is most vulnerable to hydrometeorological hazards, which is characterized by extreme weather and climate change impacts. 


\subsection{Recovery Assistance}

The frequency of devastating tropical cyclones and natural hazards in the country, especially during extreme events like in 2013, has put a significant strain on the already overstretched capacities of the Philippine government and many humanitarian agencies to respond to the aftermath of devastating disasters. The Philippines has long endured disasters that involve national and international assistance.

Based on available data from 2016 to 2019, the total cost of emergency assistance for all disasters reached $\mathrm{PhP} 2.62$ billion, in which an average of $69 \%$ was allocated for tropical cyclones and $31 \%$ was for other disasters (Figure 6). The cost of assistance to tropical cyclones was consistently higher than other disasters corollary to being the most disastrous in terms of affected population, casualties, and damages.

The national government of the Philippines and individual households bear the majority of costs caused by natural disasters (The World Bank, n.d.). The households are the ones directly facing the extend of damages, while the national government are the main agencies providing relief and recovery assistance. The Philippine government provided government emergency relief assistance in 2010-2012 which included financial assistance, food, and medicine. Together with non-government organizations, rehabilitation assistance which include housing and livelihood were provided to three million family-victims who were in most need of support.

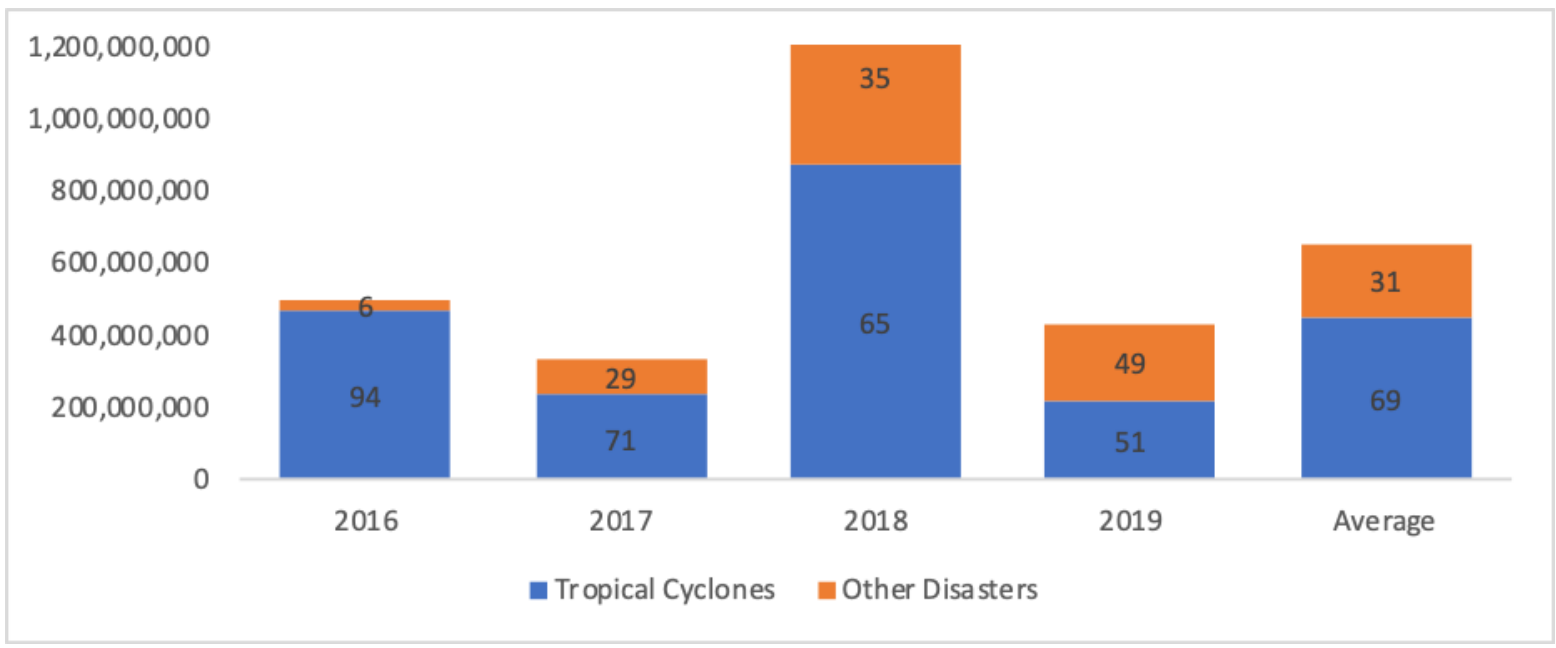

Figure 6. Cost of Assistance and Ratio (\%) for Tropical Cyclones and Other Disasters in the Philippines (2016-2019). Source: NDRRMC, Incidents Reports, various years (2010-2019)

\section{Revenue Generation Capacity of Local Governments}

Considered as a landmark legislation, the enactment of the 1991 Local Government Code (LGC) enshrined the corporate powers of the Philippine local governments to pave the way for the overall objective "to create self-reliant communities and make them more effective partners in the attainment of national goals" as stated in the Section 2 of the LGC. The Code includes assignment of functions across different levels of government, revenue sharing between the central and the local governments, resource generation/utilization authorities of 
local governments, and the participation of civil society in various aspects of local governance. These provisions are aimed at providing the framework for increased local autonomy, helping reduce interregional disparities, and in promoting economic development at the local level (Manasan, 2005).

Local governments' sources of income were the locally generated local revenues classified as (a) tax revenues which are income in the form of taxes such as business tax and real property tax, and (b) non-tax revenues which income from the fees and charges as well economic enterprises of the local governments. The external sources includes Internal Revenue Allotment, which was considered in this study.

\subsection{Annual Regular Income}

In terms of assessing revenue generation capacity by level of local government, an increasing trend in their income was observed from 2010 to 2019 except when provinces' and municipalities' income decreased in 2012 (Figure 7). This was due to the decrease in IRA allocation as a result of global recession in 2009 which was the legally base year for computing the 2012 IRA allocation for local governments. This shows that decrease in IRA allotment affect the income of most of the local governments, thereby affecting overall national income growth with the lowest recorded rate of $0.50 \%$ in 2012. The cities consistently had the highest income with an average of $42 \%$ in terms of ratio in income distribution among the levels of local government.

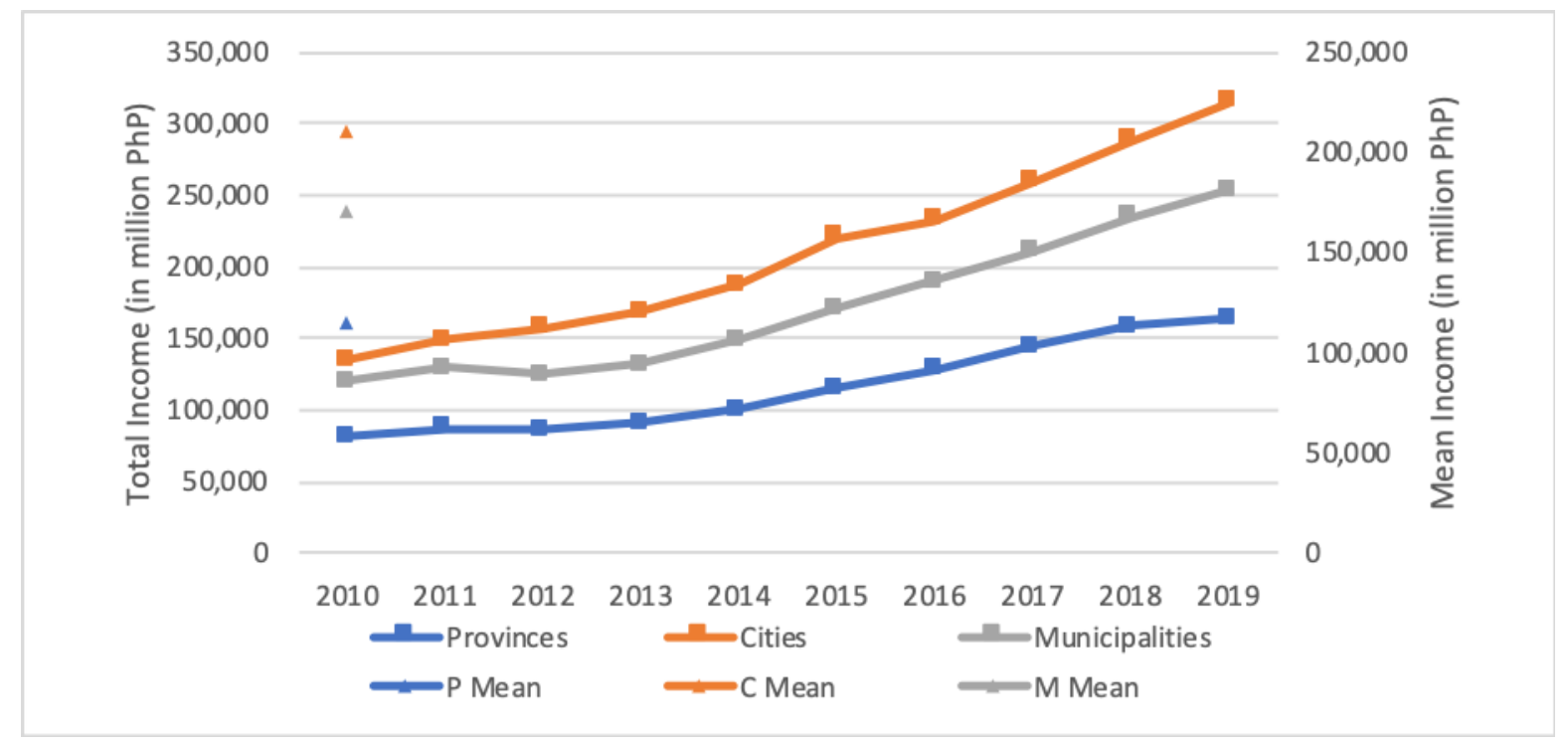

Figure 7. Annual Regular Income Based by Level of Local Government (2010-2019) Source: Bureau of Local Government Finance, LGU Fiscal Data, various years (2010-2019)

\subsection{Local Revenue Generation}

All the levels of local governments doubled their local revenue in a span of ten years. Despite this, the cities generated the biggest amount of local revenue with big margin, followed by 
municipalities, then lastly the provinces (Figure 8). While the local revenue sources of all level of government were increasing over the past decade, the differences in their local revenue were attributed to where they can source they local revenue from as stipulated in the law. The tax revenue was the dominant source of local revenue among local governments in aggregate, contributing $70 \%$ to the local revenue. Both cities and municipalities sourced their local revenue mostly from tax revenues although cities have more tax revenues they can levy from which are usually in higher amount. As such, the tax revenues levied by the cities are way higher compared to that of the provinces and municipalities. That is, $78 \%$ of the tax revenues collected by local governments were contributed by cities. Moreover, while provinces' local revenue was predominantly from non-tax revenues, the cities still generated the highest amount of non-tax revenues among the levels of local government.

\subsection{Internal Revenue Allotment (IRA)}

In terms of external sources, the municipalities got the biggest share (Figure 8). Municipalities also consistently had the biggest increase IRA received in 2010-2019. Meanwhile, provinces and cities had almost equal IRA in the same period with cities having minimally bigger external sources received. The municipalities received the biggest IRA allocation from the national government, followed by municipalities, then lastly cities. Both provinces and cities were heavily IRA dependent with $77 \%$ of their income coming from IRA while cities were able to generate local revenue which made its IRA dependence low at $42 \%$. The distribution formula for IRA, however, does not take into consideration the fiscal capacity of local governments. As such, the provision of IRA seems to be counter equalizing with respect to the fiscal capacities of local governments despite the equal sharing factor in the IRA formula.

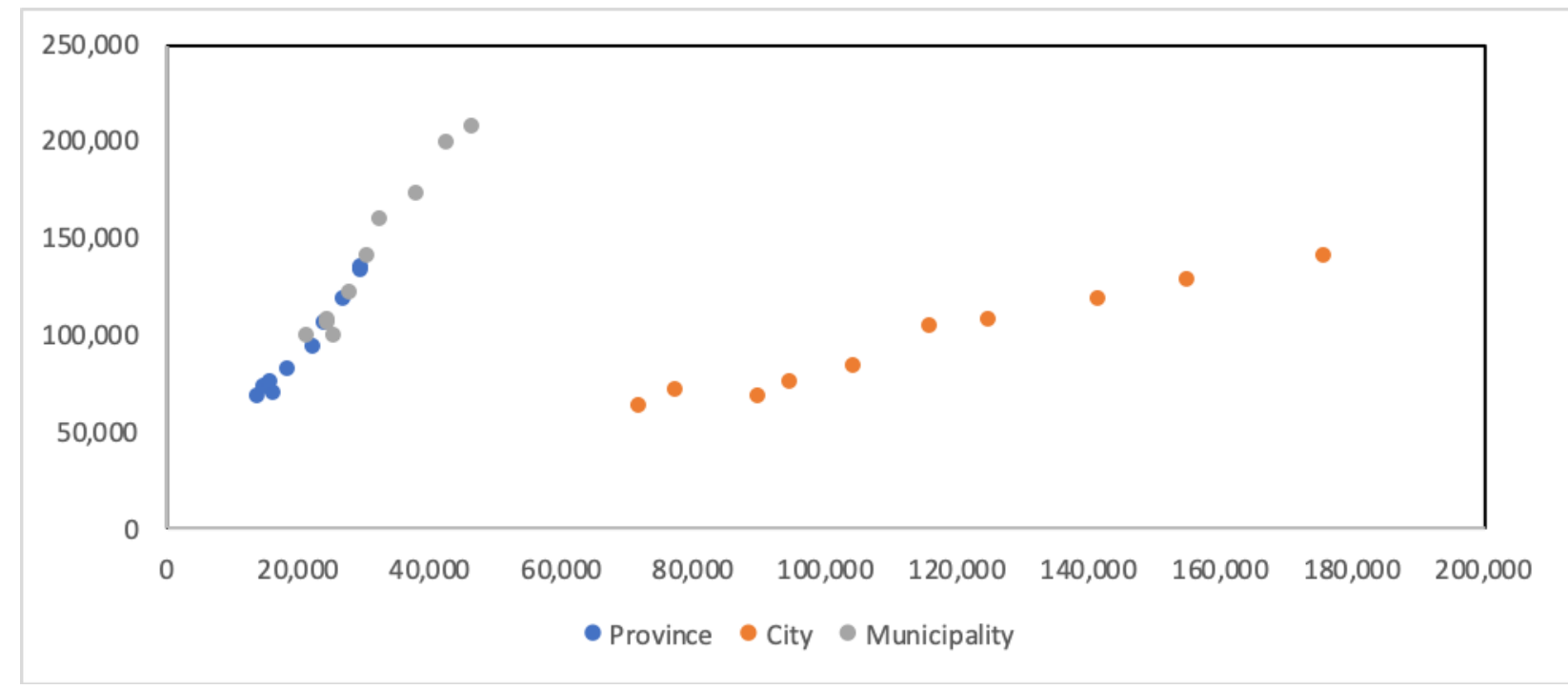

Figure 8. Sources of Income among Levels of Local Government (2010-2019)

Source: Author's estimates based on Bureau of Local Government Finance, LGU Fiscal Data, various years (2010-2019) 


\subsection{Local Revenue Dependency}

The local revenue dependency of provinces, cities, and municipalities was analyzed by computing the local revenue over the total annual regular income over the ten-year period in 2010-2019 (Figure 9). The national average was also shown using aggregated local revenue and annual regular income of the local governments.

Overall, the Philippine local governments were dependent on their local revenue with an average of 34\% in 2010-2019. Based on results, the cities were consistently dependent on its local revenue with an average of 55\% in 2010-2019. The high amount of tax revenues combined with consistent increase in its non-tax revenue contributed to the local revenue growth thereby making cities self-sufficient. While the local revenue sources of provinces were in increasing trends, the provinces remained to have low dependency on local revenue with $18 \%$. Likewise, despite the increase in local revenue, municipalities remained to have low dependence on local revenue with an average of 19\% (2010-2019).

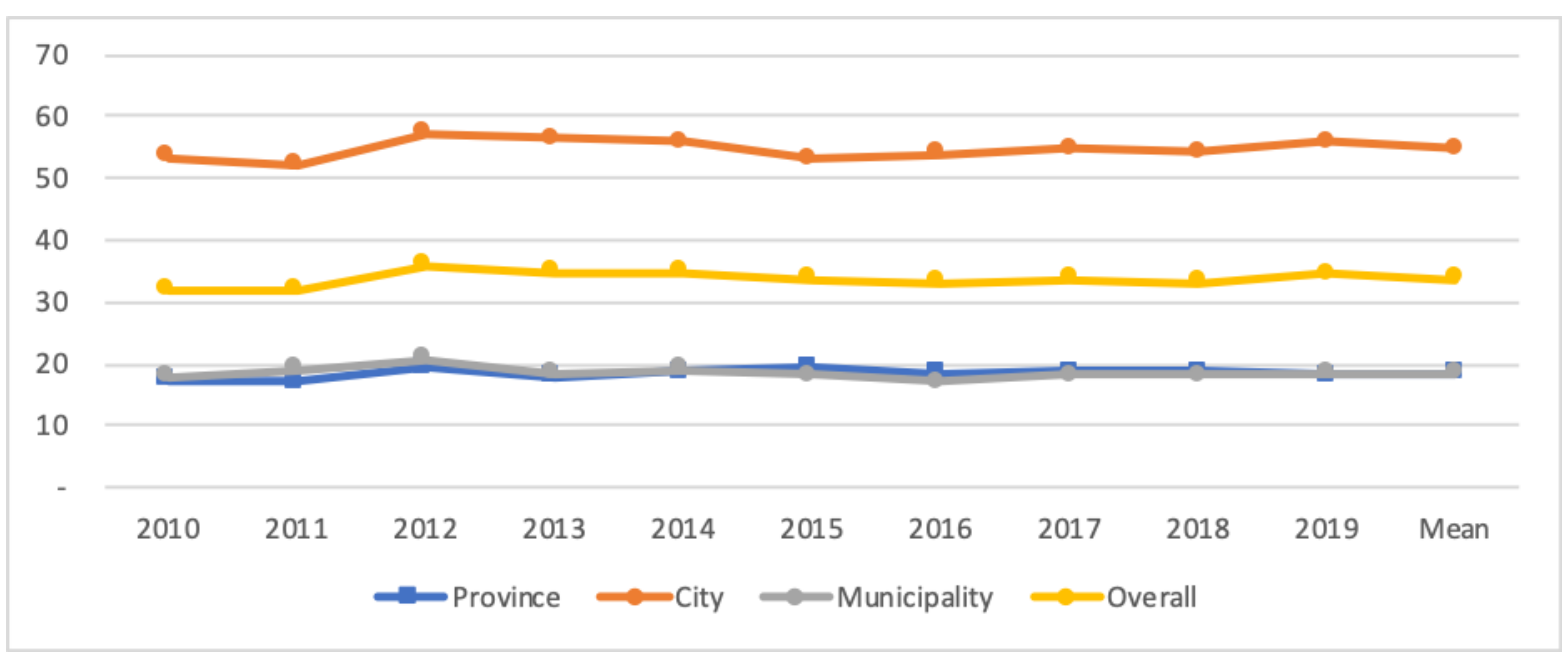

Figure 9. Local Revenue Dependency among Levels of Local Government

Source: Author's estimates based on Bureau of Local Government Finance, LGU Fiscal Data, various years (2010-2019)

\subsection{IRA Dependency}

The municipalities received the biggest IRA allocation from the national government, followed by municipalities, then lastly cities (Figure 10). Overall, the Philippine local governments remained IRA dependent at an average of $62 \%$ over the past decade. Both provinces and cities were heavily IRA dependent with $77 \%$ of their income coming from IRA while cities were able to generate local revenue which made its IRA dependence low at $42 \%$. The distribution formula for IRA, however, does not take into consideration the fiscal capacity of local governments. As such, the provision of IRA seems to be counter equalizing with respect to the fiscal capacities of local governments despite the equal sharing factor in the IRA formula.

The enactment of the LGC eliminated the national government' discretionary power on intergovernmental fiscal transfers by institutionalizing the release of IRA as automatic and 
mandatory (Diokno-Sicat, 2019). However, the downside of this is the general low efforts among local governments in raising their own local revenues which has been the case after about three decades since the enactment of the LGC. Despite the increased revenue generating powers given by the LGC, local governments maintained their dependence on IRA, a source of regular and increased patronage for local chief executives.

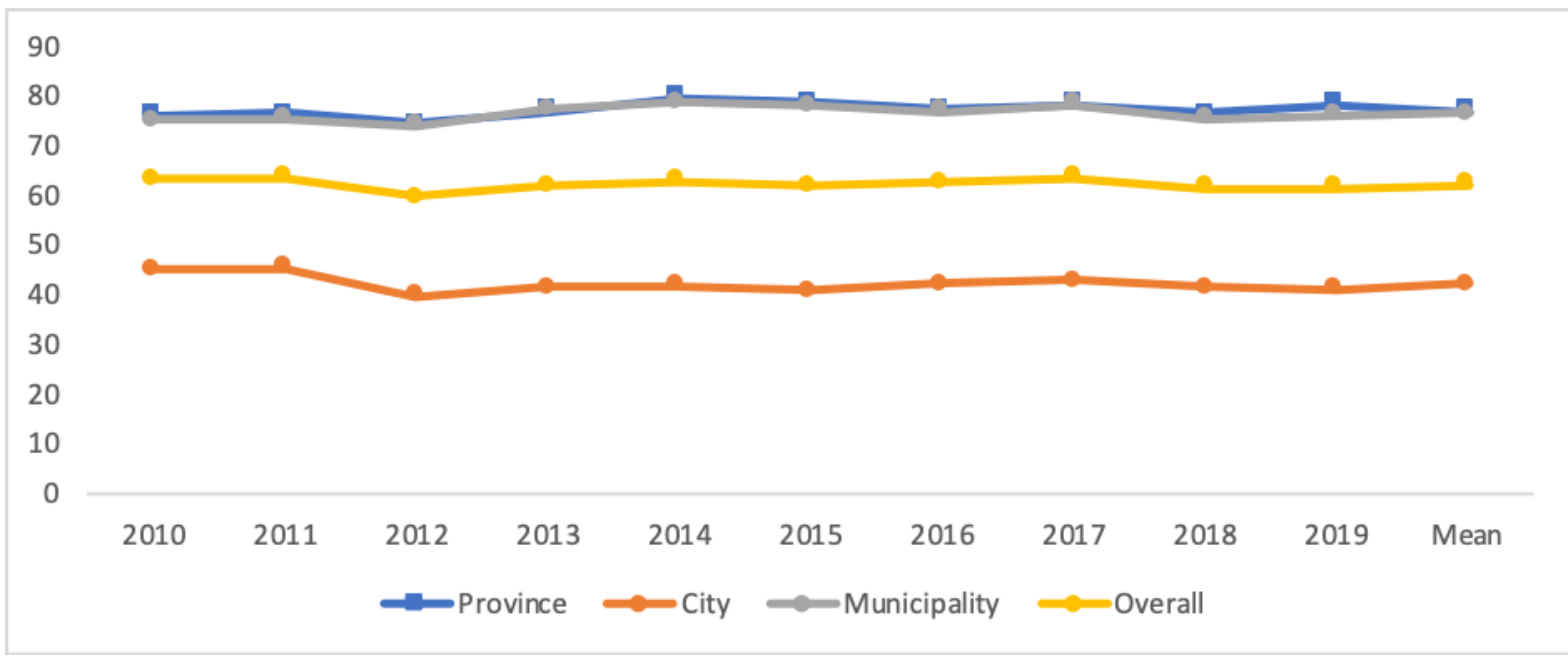

Figure 10. IRA Dependency of LGUs among Levels of Local Government

Source: Author's estimates based on Bureau of Local Government Finance, LGU Fiscal Data, various years (2010-2019)

4.6 Simple Correlation Analysis between Disaster Risk and Revenue Generation Capacity of Local Governments

As natural disasters that occur frequently have financial impacts to local governments (National Association of Development Organizations \& Rural Policy Research Institute, 2013), identifying the financial implication of tropical cyclones can provide useful information for future planning in the Philippines. Based on panel data for all levels of government in 2010-2019, the simple correlation analysis of disaster incidents on income, income growth, and sources of income confirm the negative association of disaster incidents to the revenue generation capacity among all levels of government (Table 3). Further, the result shows that cities which had the highest income and local revenue tended to have more to lose as disaster incidents increase. This is manifested by the strong negative correlation of disaster incidents to the income of all levels of government with cities having the strongest negative correlation coefficient for income (-0.73) and local revenue (-0.76).

In terms of correlation between disaster impacts to income and local revenue, while cities which had the highest local revenue have more to lose in events of high incidence of disaster, provinces tended to be the most vulnerable, followed by municipalities, as shown in the results that cities had the lowest negative coefficients. That is, local governments with higher local revenue have more to lose while local governments with lower income and local revenue are more vulnerable to the incidents and impacts of disasters.

Looking at the tax revenues, only tax revenues of cities had a negative correlation with 
disaster incidents, which have a strong correlation coefficient of -0.71 . The tax revenue collection constitutes bulk of cities' local revenues. It can be presumed the negative impact of disasters to businesses where the cities mostly source their tax revenues from in the form of business tax, thereby affecting the source of local revenue of the cities. This reflected that the major source of local revenue tended to be negatively affected by disaster incidents, thereby decreasing the income of cities.

For the non-tax-revenues, provinces' non-tax revenues had a strong negative correlation with disaster incidents (-0.81) while municipalities had a low negative correlation (-0.31). As previously discussed, more than half of the local revenue of provinces were from non-tax revenues and the non-tax revenues of municipalities were close to their collected tax revenues. The result shows that disaster incidents tended to decrease the non-tax revenues of provinces and cities, especially the provinces in which non-tax revenues constitute majority of their local revenue. Thus, disaster incidents have also impact to the collection of non-tax revenues of local governments, thereby negatively affecting the local revenue of provinces and municipalities. This implies negative impact of disaster to fees and charges and the local governments' economic enterprises where non-tax revenues are sourced from. Therefore, looking at the tax and non-tax revenues correlation results, it can be deduced that disaster incidents were associated to negative impacts to major sources of each level of the government.

The IRA of all levels of government have a strong negative correlation with disaster incidents and low negative correlation to disaster impacts (affected population, casualties, and damages). This reflects how disaster incidents and impacts tend to negatively affect the national economy as IRA is from the national internal revenue collection. Regardless of fiscal capacity, all levels of government receive IRA based on a predetermined sharing formula; as such, the IRA of all the levels of government were negatively affected at almost same level as manifested in their strong negative correlation coefficients.

In terms of IRA dependency, its strong positive correlation with cities' IRA dependency can be presumed that because of the highly negative impact of disaster to the tax revenues, the cities turn to IRA to make up for the losses in its local revenue as caused by high disaster incidents. Consequently, cities' local revenue dependency had negative correlation with disasters with a low of -0.32 . Therefore, disasters tend to lead self-sufficient local governments to be IRA dependent when their major source of income got heavily affected by impacts of disasters.

Table 3. Simple Correlation Analysis between Disaster Impacts and Sources of Income among Levels of Government (2010-2019)

\begin{tabular}{llllll}
\hline $\begin{array}{l}\text { Correlation } \\
\text { with Disaster }\end{array}$ & $\begin{array}{l}\text { Levels } \\
\text { Government }\end{array}$ & Incidents & $\begin{array}{l}\text { Affected } \\
\text { Population }\end{array}$ & Casualties & Damages \\
\hline \multirow{4}{*}{ Income } & Province & -0.66 & -0.44 & -0.43 & -0.25 \\
& City & -0.73 & -0.36 & -0.38 & -0.16 \\
& Municipality & -0.65 & -0.44 & -0.43 & -0.24 \\
\hline Income Growth & Province & -0.44 & -0.35 & -0.49 & -0.32
\end{tabular}




\begin{tabular}{llllll} 
& City & -0.28 & 0.00 & -0.25 & -0.17 \\
& Municipality & -0.35 & -0.28 & -0.46 & -0.23 \\
\hline \multirow{3}{*}{ Local Revenue } & Province & -0.71 & -0.43 & -0.44 & -0.23 \\
& City & -0.76 & -0.32 & -0.34 & -0.12 \\
& Municipality & -0.62 & -0.41 & -0.41 & -0.24 \\
\hline \multirow{2}{*}{ Tax Revenues } & Province & 0.81 & 0.36 & 0.51 & 0.14 \\
& City & -0.71 & 0.06 & -0.05 & 0.16 \\
& Municipality & 0.31 & -0.10 & 0.15 & -0.02 \\
\hline \multirow{2}{*}{ Non-Tax } & Province & -0.81 & -0.36 & -0.51 & -0.14 \\
& City & 0.71 & -0.06 & 0.05 & -0.16 \\
& Municipality & -0.31 & 0.10 & -0.15 & 0.02 \\
\multirow{2}{*}{ IRA } & Provinces & -0.68 & -0.44 & -0.44 & -0.25 \\
& City & -0.67 & -0.42 & -0.41 & -0.23 \\
\hline \multirow{2}{*}{ IRA } & Municipality & -0.68 & -0.43 & -0.43 & -0.24 \\
Dependency & Province & -0.48 & -0.02 & -0.27 & -0.06 \\
& City & 0.61 & -0.34 & -0.15 & -0.45 \\
\multirow{2}{*}{ Local Revenue } & Municipality & -0.62 & 0.07 & -0.06 & 0.04 \\
\hline \multirow{2}{*}{ Dependency } & Province & -0.73 & -0.10 & -0.29 & 0.00 \\
& City & -0.32 & 0.40 & 0.44 & 0.48 \\
& Municipality & 0.43 & 0.31 & 0.27 & 0.11 \\
\hline
\end{tabular}

Source: Author's estimates based on Bureau of Local Government Finance, LGU Fiscal Data, various years (2010-2019); NDRRMC, Incidents Reports, various years (2010-2019)

\section{DRRM Capacity}

Recognizing DRRM as an integral part of development, the Philippines is a signatory to global policy frameworks and international agreements such as the Sendai Framework for Disaster Risk Reduction 2015-203, the United Nations (UN) Agenda 2030 for Sustainable Development Goals, and the Paris Agreement within the UN Framework Convention on Climate Change (Center for Excellence in Disaster Management and Humanitarian Assistance, 2018). Aligned to this, the enactment of the Philippine Disaster Risk Reduction and Management Act in 2010 which aims to strengthen the capacity of the government through decentralized powers, responsibilities, and resources. Alongside this is the preparation of the National DRRM Framework Plan which recognized the role of local governance in realizing "safe, adaptive, and disaster-resilient Filipino communities" (Philippines, 1993).

As the DRRM frontliners at the local level, the local governments, headed by their local chief executive, shall create Local DRRM Council, appoint Local DRRM Officer, and develop Local DRRM Plan (National Economic and Development Authority, 2020). By virtue of decentralization, DRRM is among the responsibilities devolved to local governments (Center for Excellence in Disaster Management and Humanitarian Assistance, 2018). Given the multitude of devolved functions to local governments, to ensure budget allocation for DRRM, 
the PDDRM Act stipulates the allocation of the estimated 5\% of estimated revenues for Local DRRM Fund. This fund is a ratio of $70 \%$ for disaster prevention, mitigation and preparedness and 30\% for Quick Response Fund (QRF) post-disaster interventions (Commission on Audit, 2014).

Likewise, capacity-building interventions on "Building Resilient Local Economy in Changing Climate" was rolled out to local governments starting 2017, recognizing the need for local governments to be entrepreneurial and to ensure that local economic development initiatives are aligned towards reducing disaster risks (Local Government Academy, 2017). Mainstreaming climate change in local economic development strategies was captured in the Climate Change Act of 2009 in light of the country's vulnerability to disaster risks exacerbated by climate change.

In analyzing DRRM performance of the local governments, the differences in their revenue generation capacity as well as differences in exposure and extent of disasters impacts at the local level were considered. The analysis of DRRM performance of the local governments in relation to their revenue generation performance and disaster risks were manifested through their Local DRRM Fund (LDRRMF) appropriation and actual collection.

Looking at the aggregated data, the LDRRMF appropriation of all local governments in 2018 was $\mathrm{PhP} 24.79$ billion (Figure 11). By looking at the income generated by local governments in 2018, which was a total of PhP 68.59, the actual LDRRMF appropriation was only a third of the supposed LDRRMF appropriation. This reflected that poor fiscal planning among local governments (Manasan, 2005). As such, people are deprived of more DRRM interventions that could be provided at the local level.

In assessing the DRRM capacity by level of government, the study found out that municipalities have the biggest LDRRMF appropriation and actual collection among the tiers of local government, surpassing cities which had the biggest income. Moreover, provinces exceeded the cities when it comes to ratio of LDRRMF actual collection in relation to appropriation, thereby making the highest-income cities as the lowest in terms of ratio of LDRRMF actual collection.

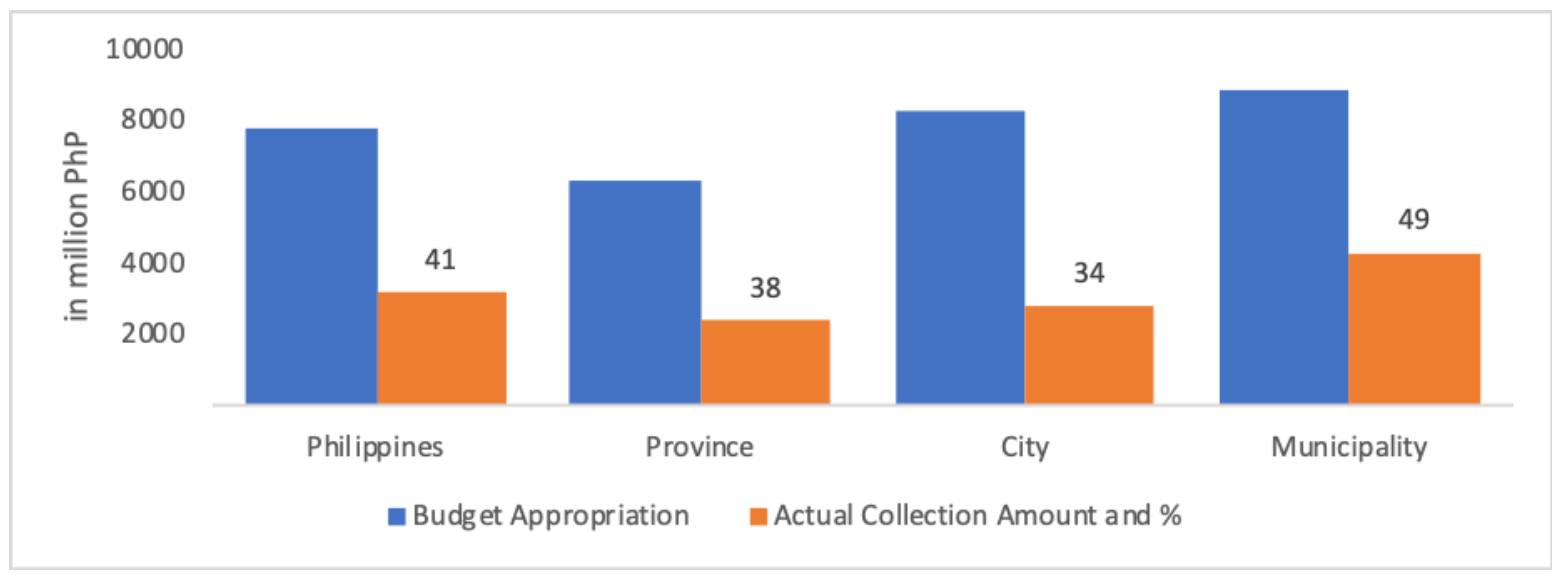

Figure 11. LDRRMF Appropriation versus Actual Amount and Ratio (\%) by Level of Local 
Government (2018). Source: Bureau of Local Government Finance, LDRRMF Report. 2018

5.1 Correlation Analysis between LDRRMF and Revenue Generation Capacity of Local Governments

Based on simple correlation analysis by level of government, the income was strongly associated to LDRRMF budget (Table 4). Moreover, local revenue and IRA have strong association with LDRRMF budget and actual collection; although IRA has a perfect association (1.00), thereby stronger correlation than local revenue (0.74). This shows that LDRRMF appropriation has a strong association with IRA; and that as IRA increases, the LDRRMF actual collection tended to increase. From this, it can be inferred why IRA-dependent municipalities had the biggest LDRRMF appropriation and collection for LDRRMF among all levels of government as municipalities got the biggest allocation of IRA. Further, this confirmed why cities had the lowest ratio of LDRRMF actual collection in relation to LDRRMF appropriation although it had the biggest local revenue. Likewise, among the local government types, both provinces and municipalities depend most of its income to IRA while cities depend on its local revenue.

Additionally, only IRA has the only positive correlation, in low degree, when it comes to ratio of actual collection and ratio of QRF in relation to appropriation. Thus, it shows why cities had realized the lowest ratio of actual collection as cities received the lowest IRA in real figures.

The result reveals that IRA plays a crucial role in the performance of DRRM mandates of the local governments, specifically in the appropriation and actualization of resources for LDRRMF. It seems that IRA provides resources in which local governments with less income depend on to perform their functions to allocate LDRRMF from their regular sources of income; however, while IRA provides additional resources to local governments with high income, it does not seem to incentivize them to allocate for LDRRMF.

Table 4. Simple Correlation Analysis between LDRRMF and Revenue Generation Capacity of Local Governments

\begin{tabular}{llllll}
\hline $\begin{array}{l}\text { Correlation with Revenue } \\
\text { Generation Performance }\end{array}$ & $\begin{array}{l}\text { LDRRMF } \\
\text { Budget }\end{array}$ & $\begin{array}{l}\text { Actual } \\
\text { Collection }\end{array}$ & $\begin{array}{l}\text { \% } \\
\text { Collection }\end{array}$ & & \\
\hline Income & 0.99 & 0.96 & -0.02 & -0.29 & 0.03 \\
Local Revenue & 0.83 & 0.74 & -0.38 & -0.58 & -0.30 \\
IRA & 0.99 & 1.00 & 0.21 & -0.08 & 0.23 \\
\hline
\end{tabular}

Source: Author's own computation based on data from Bureau of Local Government Finance, 2020

The mismatch between institutional responsibilities and capacities, particularly at the local level, has been identified as a major impediment to effective implementation of DRRM (Commission on Audit, 2014). This observed condition is likely to contribute to the non-performance of their DRRM functions in spite of the recurrent and catastrophic damages of disasters which continue to negatively affect their income. 
Moreover, we can speculate the culture of disaster in the Philippines wherein the regularity of disaster seems to be a normal part of daily life of people and was being used only as a political grandstanding among politicians during election period (Bankoff, 2003), thus DRRM was reactionary in nature. Furthermore, the Philippine local governments are characterized by frequent turnover of administrations, a weak and highly politicized bureaucracy, major families that have penetrated the administrative and political wings of the government. That is why despite enactment of PDRRM-2010, the 2014 DRRM Audit report states that the patronage system forms the socio-cultural foundation of the current disaster management system in the Philippines (Commission on Audit, 2014). Since 2018 was not an election period in the Philippines, we can assume this as a factor resulting to low actual collection ratio aside from the fact that local governments have multitudes of devolved functions they have to perform using their limited resources which is another factor to consider. That is, the political will of the local chief executive comes into play in fulfilling the DRRM mandates of the local governments which manifests through their LDRRMF budget and actual collection.

\section{Discussion}

The Philippines has remained to be one of the disaster risk countries in the world in 2010-2019. The country is most vulnerable to the impacts of hydrometeorological hazards wherein the most catastrophic damages and deadliest natural disasters were the recurrent tropical cyclones averaging 18 annually over the past decade.

Due to its geographical location, the Philippines will continue to bear the burden of natural disasters. This may sound like a tragic fate given that natural disasters will continue to strike the country wherein the impacts have been exacerbated by climate change which will only bring about more, recurrent, and stronger disasters. As such, there is no other recourse but to intensify DRRM in the country. While local governments have multitudes of devolved functions, investing on DRRM should be among its top priorities.

About three decades after the corporate powers of the Philippine local governments were enshrined through the enactment of the Local Government Code of 1991, yet the local governments have not fully harnessed their corporate powers. The impacts of disasters to local economy is one of the risks of disasters, which some local jurisdictions are most exposed to. Moreover, the inequality in the availability of resources among local governments as a consequence of natural disasters could have impact on the overall standard and provision of services and infrastructure in more disaster-prone areas of the country (Commission on Audit, 2014).

Furthermore, the national laws and framework on DRRM and CCA laws identified the need to focus on developing the capacity of local governments - for CCA, it is the need to ensure that economic development initiatives contribute to reducing disaster risks, while for PDDRM Act, it is addressing the need to ensure DRRM investment through allocation of LDRRMF sourced from the revenues of the local governments. Budget constraints was identified as one of the critical constraints for resilience-building in the country in which overcoming it was addressed through enactment of the Philippine DRRM Act which enforces 
local governments to set aside certain portion of their annual regular income for DRRM.

However, compliance to the DRRM-related law in the country seem to have neither punishment nor incentive for local governments as manifested by the general low appropriation and collection of LDRRMF among local governments. It may be seen as administrative in nature and just among the multitudes of devolved mandates the local governments have to deliver. While the law encourages local governments to invest on DRRM, the current system, however, puts local governments with lower income at a disadvantage as they have lower revenues and thus, less available resources for their calamity fund.

For disaster rehabilitation and recovery, bulk of the budget is in the national government although local governments are also mandated to appropriate QRF for post-disaster efforts. Since there is a budget and regular assistance coming from the national, the local governments tended to be dependent on external assistance, thereby seemingly less pressure for them to efficiently allocate and actualize their QRF appropriation which is part and parcel of their DRRM mandates. Whether they allocate resources or not, assistance from the national government is sure to come not to mention the international aids and grants that come when disasters struck the country.

Therefore, the revenue generation capacity of local governments are crucial to strengthen their DRRM capacity. However, the current revenue sharing set up among local governments as stipulated in the law contribute to the vulnerability of local governments with lower income. The sourcing of local revenue tends to be more favorable to cities. Moreover, the allocation of IRA was shared equally despite local governments' fiscal capacity and was based on predetermined formula which tends to favor higher income local governments. Moreover, IRA serves as a regular source of income to all local governments despite their fiscal capacity. When disaster heavily affected their source of local revenue, disasters tend to turn self-sufficient local governments to become IRA dependent. Thus, disasters deter local fiscal autonomy of local governments, breed dependency, lead self-sufficient local governments to be IRA-dependent, thus, defeating the purpose of local autonomy which is the very essence of the enactment of the Local Government Code of 1991.

Adding complexities to this is the culture of disaster in the Philippines wherein the regularity of disasters has been embedded as normal part of life resulting to people carrying the burden by themselves through coping mechanisms while it provides for elite capture being used as a political grandstanding among politicians (Bankoff, 2003). The Philippine local governments are characterized generally as weak and highly politicized bureaucractic local agency (Commission on Audit, 2014).

The varying income among local governments create disparity not just in local growth but also in performing their DRRM mandates. Addressing disparity in revenue generation and the complexities in sourcing the local revenue are crucial factors to realize disaster-resilient local economy in the Philippines. 


\section{References}

Kreft, S., Eckstein, D., \& Melchior, I. (2016). Global CLimate Risk Index 2017. Berlin: Germanwatch e.V.

Cinco, T., de Guzman, R., Ortiz, A., Delfino, R., Lasco, R., Hilario, F., . . \& Ares, E. (2016, February 9). Observed trends and impacts of tropical cyclones in the Philippines. International Journal of Climatology(36), 4638-4650. https://doi.org/10.1002/joc.4659

The World Bank. (2020, April 13). The World Bank. Retrieved July 2020, from https://www.worldbank.org/en/news/feature/2020/04/09/the-philippines-transferring-the-costof-severe-natural-disasters-to-capital-markets

The World Bank. (n.d.). Natural Disaster Risk Management in the Philippines: Poverty Alleviation through Disaster Reduction. The World Bank.

Center for Excellence in Disaster Management and Humanitarian Assistance. (2018). Philippines Disaster Management Reference Handbook.

Manasan, R. (2005). Local Public Finance in the Philippines: Lessons in Autonomy and Accountability. Philippine Journal of Developemnt, XXXII(2), 54-79.

Asian Development Bank. (2016). Local Government Finance and Fiscal Decentralization Reform Program, Subprogram 2: Report and Recommendation of the President. Metro Manila, Philippines: Asian Development Bank.

National Economic and Development Authority. (2020). Disaster Rehabilitation and Recovery Planning Guide. Pasig City, Philippines: National Economic and Development Authority.

Commission on Audit. (2014). Assessment of DRRM at the Local Level. Manila, Philippines: Commission on Audit.

Bankoff, G. (2003). Cultures of disaster; Society and natural hazards in the Philippines. London: Routledge. https://doi.org/10.4324/9780203221891

Christoplos, N. (2015). Anchoring climate change adaptation in local economic development in Viet Nam. Danish Institute for International Studies.

Benson, C. (1997). The economic impact of natural disasters in the Philippines. ODI.

The World Bank. (n.d.). Natural Disaster Risk Management in the Philippines: Enhancing Poverty Alleviation through Disaster Reduction. The World Bank.

Local Government Academy. (2017). Building Resilient Local Economy. Manila, Philippines: Local Government Academy.

National Association of Development Organizations \& Rural Policy Research Institute. (2013). Financial Planning for Natural Disasters: A Workbook for Local Governments and Regions. National Association of Development Organizations. 


\section{Macrothink}

Journal of Public Administration and Governance ISSN 2161-7104 2020, Vol. 10, No. 4

Department of the Interior and Local Government. (2019). Philippine Local Governments.

Commission on Audit. (2014). Assessment of DRRM at the Local Level. Manila, Philippines: Commission on Audit.

Bureau of Local Government Finance. (2020). LDRRMF Report.

Bureau of Local Government Finance. (n.d.). LGU Fiscal Data. Retrieved July 2020, from http://blgf.gov.ph/lgu-fiscal-data/

National Disaster Risk Reduction and Management Council. (2020). Incidents Report.

National Disaster Risk Reduction and Management Council. (2020). Tropical Cyclones Incidents Report.

Diokno-Sicat. (2019). Philippine (Metro Manila) Case Study on Municipal Financing. Manila: UNESCAP.

Philippines. (1993). The Local Government Code of 1991: the Key to National Development. Metro Manila: Cacho Pub. House.

UNESCAP. (2019). Asia Pacific Disaster Report 2019. Bangkok, Thailand: UNESCAP.

Chen, G. (2019). Assessing the Financial Impact of Natural Disasters on Local Governments. Public Financial Publications, Inc., 22-41. https://doi.org/10.1111/pbaf.12245

Brown, K. (1993, December 1993). The 10-Point Test of FInancial Condition: Toward an Easy-to-Use Assessment Tool for Smaller Cities. Government Finance Review.

Philippines. (n.d.). Disaster Preparedness. Retrieved from Official Gazette: https://www.officialgazette.gov.ph/aquino-administration/disaster-preparedness/

\section{Copyright Disclaimer}

Copyright for this article is retained by the author(s), with first publication rights granted to the journal.

This is an open-access article distributed under the terms and conditions of the Creative Commons Attribution license (http://creativecommons.org/licenses/by/4.0/). 